\title{
Climate change and biometeorology, the International Society of Biometeorology and its journal: a perspective on the past and a framework for the future
}

\author{
Paul John Beggs
}

Received: 29 October 2012 /Revised: 2 June 2013 / Accepted: 6 June 2013 / Published online: 26 June 2013

(C) The Author(s) 2013. This article is published with open access at Springerlink.com

\begin{abstract}
Anthropogenic climate change is inherently a biometeorological issue. As such, it would be reasonably expected that the International Society of Biometeorology (ISB) and its journal, International Journal of Biometeorology (IJB), would have had climate change feature prominently in their activities, articles etc., and to therefore have made a substantial and valuable contribution to the science of the issue. This article presents an analysis of climate change science in ISB and $I J B$. The analysis focusses on climate-change-related publications by ISB Presidents found through searches of Thomson Reuters Web of Science; contributions to the Intergovernmental Panel on Climate Change's (IPCC's) Working Group II (WGII) by ISB Presidents; and climate change-related publications in $I J B$ found through searches of Thomson Reuters Web of Science. The results demonstrate that the ISB, as represented by its recent, current, and future Presidents, is actively engaged in climate change research and the production of scholarly climate change publications. For example, ISB Presidents have contributed as authors to all four IPCC WGII Assessment Reports, with some Presidents having contributed to more than one Assessment Report or several chapters of the one report. Similarly, it is evident that the $I J B$ is increasingly attracting and publishing climate-change-related articles, with such articles generally having greater impact (as indicated by citations) than other $I J B$ articles. Opportunities for the ISB to provide an internal framework for, and showcase, its climate change work are described. Such opportunities, if enacted, would complement the recent creation of two $I J B$ climate change Field Editor positions.
\end{abstract}

P. J. Beggs $(\bowtie)$

Department of Environment and Geography, Faculty of Science, Macquarie University, Sydney, New South Wales 2109, Australia e-mail: paul.beggs@mq.edu.au
Keywords Climate change - Global warming · Biometeorology $\cdot$ ISB $\cdot I J B \cdot$ Intergovernmental Panel on Climate Change

\section{Introduction}

Biometeorology can be defined in various ways. As described on the inside front cover of the International Journal of Biometeorology $(I J B)$, it is the study of "interactions between living organisms and factors of the natural and artificial atmospheric environment", defining living organisms as extending "from single cell organisms, to plants and animals, including humans" (Sheridan 2012). While meteorology per se has traditionally been distinguished from climatology in part by its temporal scale, focussing on weather and atmospheric variability over short periods, modern institutional (and other) uses of the term are more inclusive, with, for example, the American Meteorological Society (AMS) publishing journals and running meetings on climate and climatology as well as meteorology. Similarly, the World Meteorological Organization (WMO) "is the United Nations system's authoritative voice on weather, climate and water" (WMO 2009). This too applies to biometeorology, which encompasses study of the above mentioned interactions at all time and space scales.

In this context, anthropogenic climate change is inherently a biometeorological issue. It is caused by human activity, and it impacts all living organisms. Indeed, climate change involves the whole climate system, with the biosphere being one of the five major components of this system. A climate system perspective of biometeorology is thus instructive, and could be encapsulated in a definition of it focussed on interactions between the biosphere and the atmosphere.

With this intimate connection between climate change and biometeorology, it would be reasonably expected that the 
International Society of Biometeorology (ISB) and its journal, $I J B$, would have had climate change feature prominently in their activities, articles etc., and to therefore have made a substantial and valuable contribution to the science of the issue. This article presents an analysis of climate change science in ISB and $I J B$. While there have been reflections on topics within biometeorology previously, such as a series of articles in the 40th Anniversary issue of $I J B$ which focussed on animal biometeorology (Johnson 1997), human biometeorology (Höppe 1997), and urban human biometeorology (Jauregui 1997), and more recently McGregor's (2012) "progress report" review of human biometeorology, rarely, if ever, have there been published reflections on the Society's and the Journal's performance in various respects.

\section{Materials and methods}

Three approaches were used to analyse climate change science in ISB and $I J B$ :

1. An examination of climate-change-related publications by ISB Presidents;

2. An examination of contributions to the Intergovernmental Panel on Climate Change Assessment Reports by ISB Presidents; and

3. An examination of climate change-related articles published in $I J B$.

Details of each approach are presented in turn in the following.

The examination of climate change-related publications by ISB Presidents involved searches in the research database Thomson Reuters' Web of Knowledge, Web of Science. Searches were over the 'Timespan' of 'All Years' (detailed below), and were conducted on 28 October 2012 on the '201210-26' update. All citation databases available in Web of Science were included in the searches, and it should be noted that coverage is variable according to database, extending from 1992 to present for the three subject-based citation indexes and 1990 to present for the two conference proceedings citation indexes. The search was limited to ISB Presidents rather than all ISB Executive Board members or all Society members because President is the highest position within the Society, elected by the ISB members, and responsible for the general achievement of the general aims of the Society. The ISB Presidents examined were the current President, the current Past President (the author of this article), the three previous Past Presidents, and the next President (the current PresidentElect). Searches for the search topic term "climate change" and each of these Presidents as author were conducted.

\footnotetext{
${ }^{1}$ In Web of Science, double quotation marks around the topic search terms finds only exact matches for the terms.
}

The examination of contributions to the Intergovernmental Panel on Climate Change Assessment Reports by ISB Presidents involved electronic searches for the above listed Presidents names of the PDFs of the four IPCC Working Group II Assessment Reports. Working Group II was selected because it is the Working Group that focusses on the impacts of climate change, the aspect of climate change that biometeorologists and biometeorology have typically had the greatest affinity for. A contribution was defined as any type of author or editor.

The examination of climate-change-related articles published in $I J B$ was also conducted through searches in Web of Science as detailed above except they were conducted on 10 October 2012 on the '2012-10-10' update. The first of these searches was for items published including the search topic term "climate change" and the publication name "International Journal of Biometeorology". For comparison, the second search was for items published including just the publication name "International Journal of Biometeorology". Results of the first search were queried using the 'Authors' feature in Web of Science in order to facilitate an assessment of the most prolific authors of climate change-related articles in the Journal. 'Citation Reports' for both searches were created in Web of Science in order to produce data on the number of published items each year and the number of citations of these items each year.

\section{Results}

The number of climate-change-related articles by ISB Presidents in Web of Science is shown in Table 1. All six Presidents have published climate change-related articles, ranging from seven by President Hoeppe to 16 by President-Elect Schwartz. In total, these six ISB members alone have contributed 71 climate-change-related articles as covered by Web of Science.

Contributions as authors to IPCC Working Group II Assessment Reports by ISB Presidents are shown in Table 2. Four of the six ISB Presidents examined have been such IPCC authors, with contributions to the Second, Third and Fourth Assessment Reports, but not the First. President Burton has made the greatest contribution, including to three chapters and one Summary for Policymakers, spread over two Assessment Reports (the Third and Fourth). Contributions by the other three Presidents have focussed on the Human Health chapter.

A total of 156 "climate change" articles have been published in $I J B$ since 1992. This represents $16 \%$ of the 970 articles published in the journal since 1992. The number of "climate change" items and the total number of items published in the $I J B$ in each year from 1992 to 2012 is shown in Fig. 1. The percentage of "climate change" articles has generally increased over this time (Fig. 2), starting at low levels of 
Table 1 Number of "climate change" articles by International Society of Biometeorology (ISB) Presidents serving from 1999 through to 2017 as of 28 October 2012. Numbers are based on searches for full ISB President name (i.e. surname plus both first and middle name initials, where the latter exists). Numbers will therefore exclude articles that included only surname and first name initial for ISB Presidents with a middle initial

\begin{tabular}{lll}
\hline ISB president & $\begin{array}{l}\text { Period of } \\
\text { presidency }\end{array}$ & $\begin{array}{l}\text { Number of "climate } \\
\text { change" publications }\end{array}$ \\
\hline Mark D. Schwartz $^{\mathrm{a}}$ & $2014-2017$ & 16 \\
Glenn R. McGregor & $2011-2014$ & 12 \\
Paul J. Beggs & $2008-2011$ & 11 \\
Laurence S. Kalkstein & $2005-2008$ & 11 \\
Peter Hoeppe & bon-2005 & 7 \\
Ian Burton & $1999-2002$ & 14 \\
Total & & 71 \\
\hline
\end{tabular}

${ }^{\text {a }}$ Current President-Elect

${ }^{\mathrm{b}}$ Includes searches for Peter Höppe and Peter Hoeppe

0-9 \% over much of the $1990 \mathrm{~s}$, and increasing to the highest levels around $30 \%$ in the last two complete years (2010 and 2011). With the exception of two anomalously low years, the number of "climate change" articles in $I J B$ has increased exponentially over this period (Fig. 1), with the largest number of such articles in a single year, 25, occurring in 2011 (noting that 2012 data is for part year only).

The most prolific authors of the 156 "climate change" articles in the $I J B$ are shown in Table 3. Several at the top of the list, including Annette Menzel, Nicole Estrella, and Timothy Sparks, work from the Chair of Ecoclimatology at the Technische Universität München. The list also includes a number of ISB

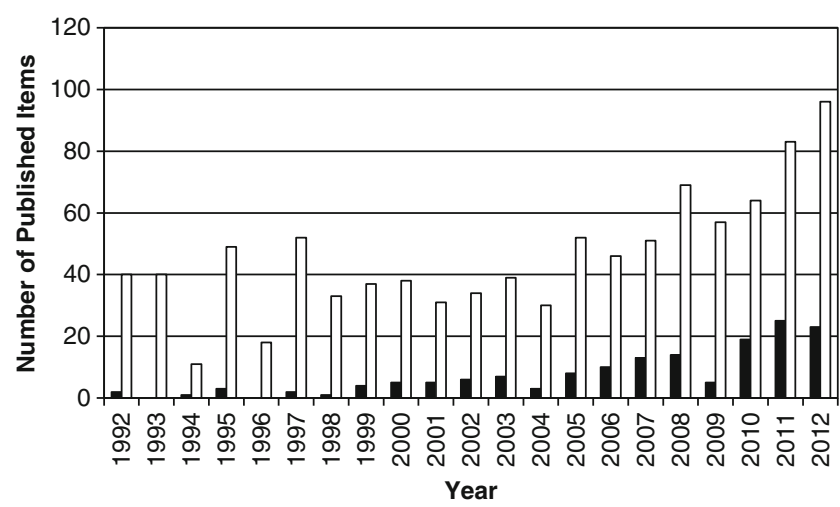

Fig. 1 The number of items published in the International Journal of Biometeorology in each year from 1992 to 2012 (white columns), and including the search topic term "climate change" (black columns), from Thomson Reuters' Web of Knowledge, Web of Science (as of 10 October 2012, updated '2012-10-10')

members, including recent and current Executive Board members, Andreas Matzarakis (Vice President 2008-2011) and Glenn McGregor (current President).

Over $25 \%(2,661)$ of the $10,513 \mathrm{IJB}$ citations since 1992 have been for its "climate change" articles. Interestingly, this constitutes a much greater proportion than the corresponding proportion of climate change articles to the total number of articles published in $I J B$ reported earlier in this section $(16 \%)$. Both total and "climate change" article citations have increased exponentially over this period (Fig. 3). As with articles, the percentage of "climate change" article citations has generally increased over this time (Fig. 2), starting at a slightly higher base than the percentage of "climate change" articles themselves, of 4-10\% over much of the $1990 \mathrm{~s}$ (excluding 1992 when citations records has just started and

Table 2 Contributions as authors to Intergovernmental Panel on Climate Change (IPCC) Working Group II Assessment Reports (First to Fourth) by International Society of Biometeorology Presidents serving from 1999 through to 2017

\begin{tabular}{|c|c|c|c|c|c|}
\hline ISB president & $\begin{array}{l}\text { Period of } \\
\text { presidency }\end{array}$ & $\begin{array}{l}\text { Assessment report } \\
\text { number }\end{array}$ & Chapter number and name & Author type & Reference \\
\hline Mark D. Schwartz ${ }^{\mathrm{a}}$ & 2014-2017 & - & - & - & - \\
\hline Glenn R. McGregor & 2011-2014 & Fourth & 8 Human health & Contributing & Confalonieri et al. 2007 \\
\hline Paul J. Beggs & 2008-2011 & Fourth & 8 Human health & Contributing & Confalonieri et al. 2007 \\
\hline \multirow[t]{2}{*}{ Laurence S. Kalkstein } & \multirow[t]{2}{*}{$2005-2008$} & Second & 18 Human population health & Principal Lead & McMichael et al. 1996 \\
\hline & & Third & 9 Human health & Contributing & McMichael et al. 2001 \\
\hline Peter Hoeppe ${ }^{b}$ & $2002-2005$ & - & - & - & - \\
\hline \multirow[t]{4}{*}{ Ian Burton } & \multirow[t]{4}{*}{ 1999-2002 } & Third & Summary for policymakers & Drafting author & Ahmad et al. 2001a \\
\hline & & Third & 2 Methods and tools & Review Editor & Ahmad et al. 2001b \\
\hline & & Third & $\begin{array}{l}18 \text { Adaptation to climate change } \\
\text { in the context of sustainable } \\
\text { development and equity }\end{array}$ & Lead & Smit et al. 2001 \\
\hline & & Fourth & $\begin{array}{l}19 \text { Assessing key vulnerabilities } \\
\text { and the risk from climate change }\end{array}$ & Lead & Schneider et al. 2007 \\
\hline
\end{tabular}

\footnotetext{
${ }^{\mathrm{a}}$ Current President-Elect

${ }^{\mathrm{b}}$ Includes searches for Peter Höppe and Peter Hoeppe
} 


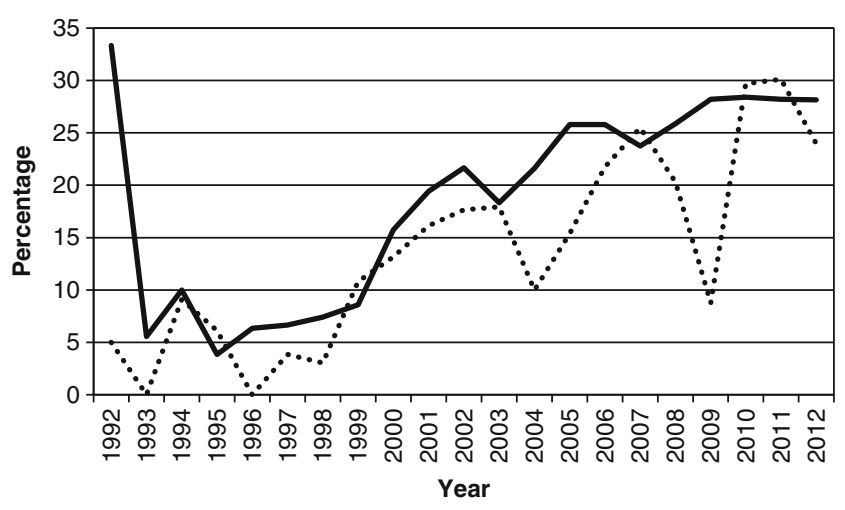

Fig. 2 Percentage of items published in the International Journal of Biometeorology including the search topic term "climate change" in each year from 1992 to 2012 (dotted line), and citations of these items expressed as a percentage of all citations of the International Journal of Biometeorology (solid line), from Thomson Reuters' Web of Knowledge, Web of Science (as of 10 October 2012, updated '2012-10-10')

numbers were very low), and increasing to the highest levels of $28 \%$ since 2009 ).

\section{Discussion}

The results presented here demonstrate that the ISB, as represented by its recent, current, and future Presidents, is actively engaged in climate change research and the production of scholarly climate change publications. Similarly, it is evident that the International Journal of Biometeorology is increasingly attracting and publishing climate change articles, with such articles generally having greater impact (as indicated by citations) than other $I J B$ articles.

It should be noted that the Web of Science analyses will have slightly underestimated the number of climate-changerelated articles by only using the term "climate change". There will be a small number of relevant articles that only use alternate terms such as 'global warming', 'greenhouse effect' etc. For example, a search for each of the six Presidents' names and using the search topic term "global warming" and excluding "climate change", found only five publications.

The contributions of the ISB to climate change research of course go way beyond those documented in the results of this

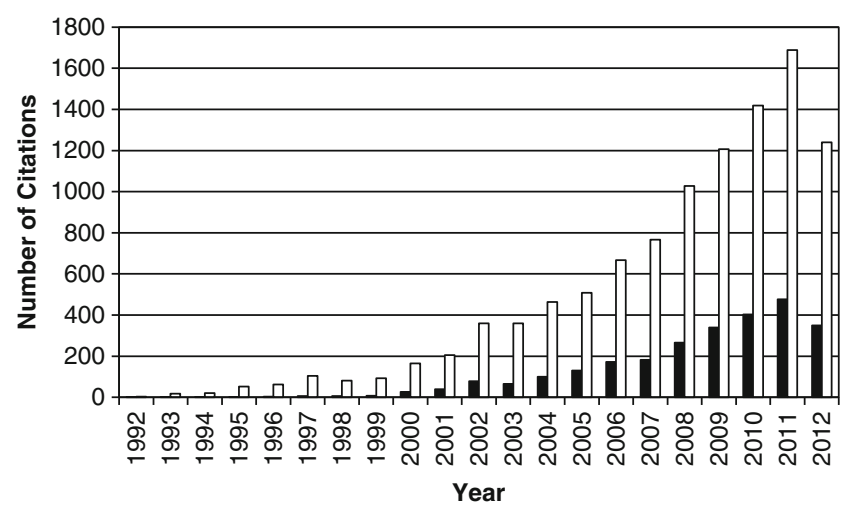

Fig. 3 Citation of items published in the International Journal of Biometeorology in each year from 1992 to 2012 (white columns), and of items including the search topic term "climate change" (black columns), from Thomson Reuters' Web of Knowledge, Web of Science (as of 10 October 2012, updated '2012-10-10')

article. Some noteworthy contributions not covered by the analysis above include participation in the IPCC review process, with, for example, Presidents Beggs, Burton, Hoeppe, and McGregor, and President-Elect Schwartz, all being acknowledged Reviewers of the IPCC WGII Fourth Assessment Report, along with a number of other members of the Society (IPCC 2007). It is also particularly noteworthy that Kristie Ebi, an IJB Field Editor, has been Head of the IPCC WGII Technical Support Unit, playing a central role in the production of the Fifth Assessment Report due for publication in 2014, and the recently published "SREX" Special Report (Field et al. 2012). Past President Burton is continuing his significant contribution to the IPCC Assessment Reports, as a Lead Author of the Fifth Assessment Report (AR5) WGII chapter on "Climate-resilient pathways: adaptation, mitigation, and sustainable development" (IPCC 2013). With respect to IPCC involvement, it is perhaps appropriate to conclude by also acknowledging the contribution of ISB members to the First Assessment Report published almost a quarter of a century ago now. Specifically, yet another Past President, Wolf Weihe, along with two other past Executive Board members, Gerd Jendritzky and Masami Iriki (a past $I J B$ Editor-in-Chief) contributed to the broad ranging Chapter 5 of the Working Group II report (Hashimoto et al. 1990).
Table 3 The most prolific authors of the 156 "climate change" articles in the International Journal of Biometeorology. Authors with the same number of articles are listed alphabetically by surname

\begin{tabular}{llllll}
\hline Author & $\begin{array}{l}\text { Number of } \\
\text { articles }\end{array}$ & Author & $\begin{array}{l}\text { Number of } \\
\text { articles }\end{array}$ & Author & $\begin{array}{l}\text { Number of } \\
\text { articles }\end{array}$ \\
\hline Menzel A & 7 & Tan JG & 4 & Kajfez-Bogataj L & 3 \\
Estrella N & 5 & Wielgolaski FE & 4 & Karlsen SR & 3 \\
Matzarakis A & 5 & Ahas R & 3 & Langford IH & 3 \\
Sparks TH & 5 & Bentham G & 3 & McGregor GR & 3 \\
Caffarra A & 4 & Donnelly A & 3 & Regniere J & 3 \\
Endler C & 4 & Emberlin J & 3 & Zheng YF & 3 \\
\hline
\end{tabular}


Two further ISB climate change book contributions are particularly noteworthy. The first volume of the Springer/ISB Biometeorology Book Series, Ebi et al. (2009), was focused on the topic of "Biometeorology for Adaptation to Climate Variability and Change" and was edited and authored largely by ISB members. The Munich Reinsurance Company book titled "Weather catastrophes and climate change: is there still hope for us?" is significant for at least two reasons. First, it included a chapter by ISB Past President Höppe (Höppe 2005), and second, it stemmed from the Geo Risks Research group of Munich Re which ISB Past President Höppe became Head of in 2005. With ISB Past President Höppe previously holding a university academic position, such an appointment speaks to the applied nature of much biometeorological research, and its relevance to both the broader community and business and industry alike.

While the analysis presented in this article does indeed portray a scholarly society and its journal (ISB and IJB respectively) that have made a substantial and valuable contribution to the science of the climate change issue, the Society at least has perhaps missed past opportunities to provide an internal framework for and showcase this work. While climate change has certainly been a strong theme of many, if not all, of the Society's recent Commissions and Study Groups, there have been no Commissions or Study Groups with Climate Change in the title. Similarly, despite the active research on climate change by many of the Society members over many years, the Society has never published a position statement on climate change [such as that by the AMS Council (2012), Royal Meteorological Society (2007), American Association for the Advancement of Science (AAAS) Board of Directors (2007) and many other scientific Societies (AAAS and 17 Other Groups 2009)].

While the recent and future Presidents of the Society, and indeed many others in the Society, have made considerable individual contributions to climate change science, it is perhaps the Society's 'Students and New Professionals' Group, the future of the Society, that is now best placed to produce a collective "ISB" statement on climate change. The current leader of this group, Simon Gosling, is well placed to coordinate this active group in development of an ISB climate change statement, being the most recent recipient (in 2011) of the ISB's triennial prize, the Tromp Scientific Award, for his article titled "Climate change and heat-related mortality in six cities Part 2: climate model evaluation and projected impacts from changes in the mean and variability of temperature with climate change" (Gosling et al. 2009).

The $I J B$ has recently progressed to explicitly include areas of climate change focus, through the introduction of "Climate Change and Ecology" and "Climate Change and Public Health" as 2 of the 12 "fields", with dedicated Field Editors, in 2011. In so doing, it has established a solid framework upon which even greater future contributions to the climate change literature can be made.
In an $I J B$ Editorial from 1993, the words of Wolf Weihe, the then ISB President, are poignant: "discussion on climate change is a new and extraordinary challenge to human biometeorology and biometeorology at large" and "we are entering a new phase in biometeorology as a science of adaptation" (Weihe 1993). This article provides evidence that the ISB and $I J B$ have been active participants in this discussion, and indeed have been a leader in aspects of climate change impacts and adaptation research.

Open Access This article is distributed under the terms of the Creative Commons Attribution License which permits any use, distribution, and reproduction in any medium, provided the original author(s) and the source are credited.

\section{References}

Ahmad QK, Anisimov O, Arnell N, Brown S, Burton I, Campos M, Canziani O, Carter T, Cohen SJ, Desanker P, Easterling W, Fitzharris BB, Forbes D, Gitay H, Githeko A, Gonzalez P, Gubler D, Gupta S, Haines A, Harasawa H, Holten JI, Jallow BP, Jones R, Kundzewicz Z, Lal M, La Rovere EL, Leary N, Leemans R, Liu C, Magadza C, Manning M, Mata LJ, McCarthy J, McLean R, McMichael A, Miller K, Mills E, Mirza MMQ, Murdiyarso D, Nurse L, Parmesan C, Parry M, Patz J, Petit M, Pilifosova O, Pittock B, Price J, Root T, Rosenzweig C, Sarukhan J, Schellnhuber J, Schneider S, Scholes R, Scott M, Sem G, Smit B, Smith J, Sohngen B, Tsyban A, van Ypersele J-P, Vellinga P, Warrick R, Wilbanks T, Woodward A, Wratt D (2001a) Summary for policymakers. In: McCarthy JJ, Canziani OF, Leary NA, Dokken DJ, White KS (eds) Climate change 2001: impacts, adaptation, and vulnerability. Contribution of Working Group II to the Third Assessment Report of the Intergovernmental Panel on Climate Change. Cambridge University Press, Cambridge, UK, pp 1-17

Ahmad QK, Warrick RA, Downing TE, Nishioka S, Parikh KS, Parmesan C, Schneider SH, Toth F, Yohe G, Ahmed AU, Ayton P, Fitzharris BB, Hay JE, Jones RN, Morgan G, Moss R, North W, Petschel-Held G, Richels R, Burton I, Kates R (2001b) Methods and tools. In: McCarthy JJ, Canziani OF, Leary NA, Dokken DJ, White KS (eds) Climate change 2001: impacts, adaptation, and vulnerability. Contribution of Working Group II to the Third Assessment Report of the Intergovernmental Panel on Climate Change. Cambridge University Press, Cambridge, UK, pp 105-143

American Association for the Advancement of Science and 17 Other Groups (2009) Letter to Members of the U.S. Senate. http:// www.aaas.org/news/releases/2009/media/1021climate_letter.pdf. Accessed 29 October 2012

American Association for the Advancement of Science Board of Directors (2007) AAAS Board Statement on Climate Change. http:// www.aaas.org/news/press room/climate change/mtg 200702/ aaas_climate_statement.pdf. Accessed 29 October 2012

American Meteorological Society Council (2012) Climate change: an information statement of the American Meteorological Society. American Meteorological Society, Boston. http://www.ametsoc.org/ policy/2012climatechange.pdf. Accessed 29 October 2012

Confalonieri U, Menne B, Akhtar R, Ebi KL, Hauengue M, Kovats RS, Revich B, Woodward A, Abeku T, Alam M, Beggs P, Clot B, Furgal C, Hales S, Hutton G, Islam S, Kjellstrom T, Lewis N, Markandya A, McGregor G, Smith KR, Tirado C, Thomson M, Wolf T (2007) Human health. In: Parry ML, Canziani OF, Palutikof JP, van der Linden PJ, Hanson CE (eds) Climate change 2007: impacts, 
adaptation and vulnerability. Contribution of Working Group II to the Fourth Assessment Report of the Intergovernmental Panel on Climate Change. Cambridge University Press, Cambridge, UK, pp 391-431

Ebi KL, Burton I, McGregor GR (eds) (2009) Biometeorology for adaptation to climate variability and change. Springer, Dordrecht

Field CB, Barros V, Stocker TF, Qin D, Dokken DJ, Ebi KL, Mastrandrea MD, Mach KJ, Plattner G-K, Allen SK, Tignor M, Midgley PM (eds) (2012) Managing the risks of extreme events and disasters to advance climate change adaptation. Special Report of Working Groups I and II of the Intergovernmental Panel on Climate Change. Cambridge University Press, Cambridge, UK

Gosling SN, McGregor GR, Lowe JA (2009) Climate change and heatrelated mortality in six cities Part 2: climate model evaluation and projected impacts from changes in the mean and variability of temperature with climate change. Int J Biometeorol 53(1):31-51. doi:10.1007/s00484-008-0189-9

Hashimoto M, Styrikovich M, Nishioka S, Rouviere C, Williams T, Ball R, Shinyak Y, Topping J, Nishioka S, Ando M, Okita T, Cheng P, Connell J, Roy P, Safiullah S, Street RB, Tebicke HL, DonatHader P, Gertis K, Jendritzky G, Jung EG, Steimle F, Tekulve E, Waschke G, Sugandhy A, Iriki M, Nishinomiya S, Washida N, Odingo R, van der Leun JC, Wratt DS, Weihe WH, Grant LD, Guinnup D, Longstreth JD, Oppenheimer M, Teramura A, Walsh MP, Nazarov I, Vladimirova NF, Yakovlev AF, Waight PJ, Ye R (1990) Human settlement; the energy, transport and industrial sectors; human health; air quality; and changes in ultraviolet-B radiation. In: Tegart WJ MG, Sheldon GW, Griffiths DC (eds) Climate change: the IPCC impacts assessment. Report prepared for Intergovernmental Panel on Climate Change by Working Group II. Australian Government Publishing Service, Canberra, pp 5-i-5-iv, 5-1-5-45

Höppe $\mathrm{P}$ (1997) Aspects of human biometeorology in past, present and future. Int J Biometeorol 40(1):19-23. doi:10.1007/BF02439406

Höppe P (2005) Effects of climate change on humans. In: Munich Re Group (ed) Weather catastrophes and climate change: is there still hope for us? Münchener Rückversicherungs-Gesellschaft, München, pp 156-165

IPCC (2007) Appendix III: Reviewers of the IPCC WGII Fourth Assessment Report. In: Parry ML, Canziani OF, Palutikof JP, van der Linden PJ, Hanson CE (eds) Climate change 2007: impacts, adaptation and vulnerability. Contribution of Working Group II to the Fourth Assessment Report of the Intergovernmental Panel on Climate Change. Cambridge University Press, Cambridge, UK, pp 899-932

IPCC (2013) Fifth Assessment Report (AR5) Authors and Review Editors: As of 12 March 2013. http://www.ipcc.ch/pdf/ar5/ar5 authors_review_editors_updated.pdf. Accessed 31 May 2013

Jauregui E (1997) The last Ms for 40th anniversary issue. Aspects of urban human biometeorology. Int J Biometeorol 40(1):58-61. doi:10.1007/BF02439413

Johnson HD (1997) Aspects of animal biometeorology in the past and future. Int J Biometeorol 40(1):16-18. doi:10.1007/BF02439405

McGregor GR (2012) Human biometeorology. Prog Phys Geogr 36(1):93-109. doi:10.1177/0309133311417942

McMichael AJ, Ando M, Carcavallo R, Epstein P, Haines A, Jendritzky G, Kalkstein L, Odongo R, Patz J, Piver W, Anderson R, Curto de
Casas S, Galindez Giron I, Kovats S, Martens WJM, Mills D, Moreno AR, Reisen W, Slooff R, Waltner-Toews D, Woodward A (1996) Human population health. In: Watson RT, Zinyowera MC, Moss RH, Dokken DJ (eds) Climate change 1995: impacts, adaptations and mitigation of climate change: scientific-technical analyses. Contribution of Working Group II to the Second Assessment Report of the Intergovernmental Panel on Climate Change. Cambridge University Press, Cambridge, UK, pp 561-584

McMichael A, Githeko A, Akhtar R, Carcavallo R, Gubler D, Haines A, Kovats RS, Martens P, Patz J, Sasaki A, Ebi KL, Focks D, Kalkstein L, Lindgren E, Lindsay S, Sturrock R, Confalonieri U, Woodward A (2001) Human health. In: McCarthy JJ, Canziani OF, Leary NA, Dokken DJ, White KS (eds) Climate change 2001: impacts, adaptation, and vulnerability. Contribution of Working Group II to the Third Assessment Report of the Intergovernmental Panel on Climate Change. Cambridge University Press, Cambridge, UK, pp 451-485

Royal Meteorological Society (2007) Statement on the Inter-Governmental Panel on Climate Change's (IPCC) Fourth Assessment Report: The Royal Meteorological Society's statement on the Inter-Governmental Panel on Climate Change's Fourth Assessment Report. http:// www.rmets.org/statement-inter-governmental-panel-climatechange $\% \mathrm{E} 2 \% 80 \% 99$ s-ipcc-fourth-assessment-report. Accessed 29 October 2012

Schneider SH, Semenov S, Patwardhan A, Burton I, Magadza CHD, Oppenheimer M, Pittock AB, Rahman A, Smith JB, Suarez A, Yamin F, Corfee-Morlot J, Finkel A, Füssel H-M, Keller K, MacMynowski D, Mastrandrea MD, Todorov A, Sukumar R, van Ypersele J-P, Zillman J (2007) Assessing key vulnerabilities and the risk from climate change. In: Parry ML, Canziani OF, Palutikof JP, van der Linden PJ, Hanson CE (eds) Climate change 2007: impacts, adaptation and vulnerability. Contribution of Working Group II to the Fourth Assessment Report of the Intergovernmental Panel on Climate Change. Cambridge University Press, Cambridge, UK, pp 779-810

Sheridan SC (ed) (2012) Int J Biometeorol 56(6)

Smit B, Pilifosova O, Burton I, Challenger B, Huq S, Klein RJT, Yohe G, Adger N, Downing T, Harvey E, Kane S, Parry M, Skinner M, Smith J, Wandel J, Patwardhan A, Soussana J-F (2001) Adaptation to climate change in the context of sustainable development and equity. In: McCarthy JJ, Canziani OF, Leary NA, Dokken DJ, White KS (eds) Climate change 2001: impacts, adaptation, and vulnerability. Contribution of Working Group II to the Third Assessment Report of the Intergovernmental Panel on Climate Change. Cambridge University Press, Cambridge, UK, pp 877912

Weihe WH (1993) The general theme for the 13th Congress of the International Society of Biometeorology from 12 to 18 September 1993 in Calgary, Canada. Int J Biometeorol 37(3):111. doi:10.1007/ BF01212619

World Meteorological Organization (2009) The World Meteorological Organization at a glance. World Meteorological Organization, Communications and Public Affairs Office, Geneva. http:// www.wmo.int/pages/about/documents/WMO990.pdf. Accessed 29 October 2012 